Sultan Qaboos University Journal of Arts \& Social Sciences

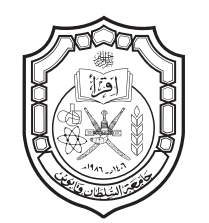

جامعة السلطان قابوس الآدان مجلة الآداب والعلوم الاجتماعية

Recovery of an Early Evidence of Castor Plant, Ricinus Communis L. from the Central Sudan and its Positioning within a World-wide Context

\begin{tabular}{c}
\hline Anwar A-Magid \\
\hline Centre for Africa Studies \\
University of the Free State \\
South Africa. \\
osmanea@ufs.ac.za
\end{tabular}




\title{
Recovery of an Early Evidence of Castor Plant, Ricinus communis L. from the Central Sudan and its Positioning within a World-wide context.
}

\section{Anwar A-Magid}

\begin{abstract}
:
Evidence of castor plant R. communis, L. is recovered from the Early Holocene archaeological site of Kabbashi Haitah in the Central Sudan and dated to c. 7700 - 7200 bp. This evidence represents the earliest botanical evidence recovered -so far- from the Central Sudan and elsewhere in Eastern Tropical Africa and the World. No evidence is found in the material culture remains which might indicate the likelihood of its being imported. Most of the ancient and traditional utilizations of castor plant are strikingly similar despite their being practised at different times in different and far apart regions in the World. This modest contribution stands to show that the wide spread and utilizations of castor plant strongly accentuate its significant and indispensable role since ancient times. It also reflects that inedible plants, as seen in the case of castor plant, were (and still are) not less important than food plant, hence stresses the need for attending to their study in a fashion equal to that of studying foodplants since prehistoric and early historic times.
\end{abstract}

Keywords. Castor-plant, plant-impressions, Central-Sudan, Food-plants, Inedible plants.

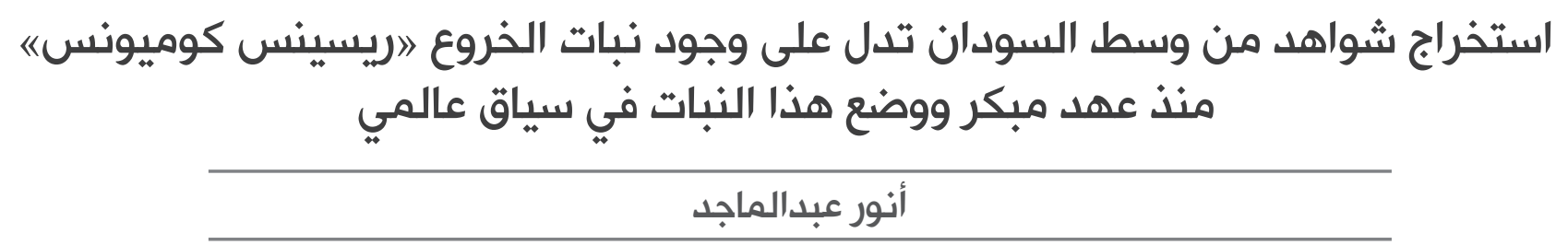

مستخلص:

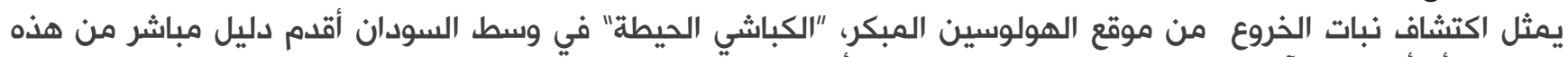

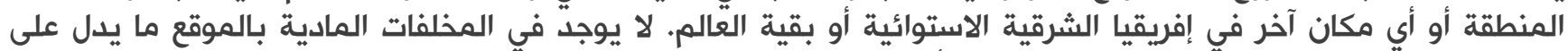

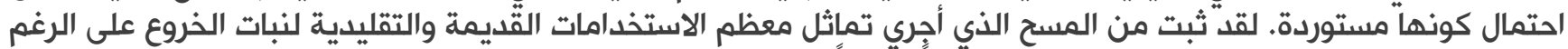

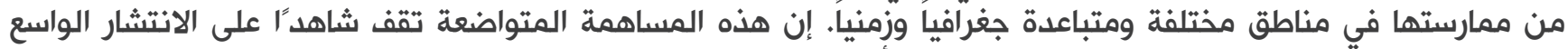

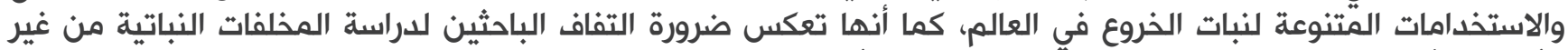
الأطعمة بأسلوب وانتظام لا يقل عن درراسة مخلفات الأطعمة النباتية منذ عصر ما قبل التاريخ والعصور التاريخية المبكرة.

الكلمات الدالة: نبات الخروع ، انطباعات نباتية ، وسط السودان ،الغذاء النباتي ، نباتات غير صالحة للغذاء 


\section{Prelude.}

Archaeobotany may be viewed as a field of research that contributes to the maximization of recovery and integration of the range of archaeological evidence in order to better understand the culture history within its environmental context and how past human populations and societies exploited and modified their surrounding environments. Therefore, archaeobotanical findings should ideally be handled and processed as an equal and inseparable part of the study and interpretation of other evidence recovered from archeological sites. However, not all the retrieved archaeobotanical evidence receive equal and undivided attention in some parts of the World (especially in Africa) where there is a general tendency to focus more on evidence pertaining to diet and food procurement.

The record of archaeological research in the Central Sudan during the last six decades partly included some archaeobotanical studies such as those published by, e.g. Arkell, A.J. 1949: pp. 108-109; 1953: pp. 80, 103, 105; Haaland. R. 1981: pp. 121-122; 1987: pp. 76-77, 227; Krzyzaniak, L. 1978: pp. 67 - 69; 1979: pp. 159 - 172; Klickowska, M. 1978: pp. 42-43; Magid, A. 1982; 1989; 1995; Magid, A. and I. Caneva. 1998; Mohammed-Ali, A.S. 1982: 60, 89, 101, 104, 138-39, 162; etc. Almost all of these studies mirror similar tendencies where their main focus has been on the study of exploitation of food plants and its development since the Early and Middle Holocene. Paradoxically, evidence of inedible plant remains was often recovered from the same archaeological contexts where evidence of foodplant was found yet their study is often confined only to their identification and documentation (Magid, A., forthcoming). Subsequently, the final analysis and interpretation are compromised.

\section{Objectives of the present work}

In light of the foregoing account, we anticipate that the present work will contribute to recent initiatives (e.g. Magid. , 2003) which were instigated in order to draw more attention to the value and advantages of researching inedible plants remains recovered from archaeological contexts. This work is engaged with a comprehensive study of an archaeobotanical evidence of inedible plant species excavated from an Early Holocene site in the Central Sudan with the main emphasis on the following issues:

1- Nature and association of the archaeobotanical evidence with its archaeological context.

2-Implications of the evidence as regards its:

a. Origin.

b.Uses.

3- A survey positioning the evidence from the Central Sudan within a world-wide context. This includes (but not confined to):

a. The main theories on the early centres of the plant.

b. Early (archaeobotanical, archaeological, textual, etc.) evidence of the plant, its uses, and their spread in the World.

c.continuity and discontinuity of different uses of the plant as seen from the traditional applications/uses of the plant in different parts of the World.

2. Nature of the archaeobotanical evidence and its association with archaeological context.

The archaeobotanical evidence consists of two impressions of seeds in pottery recovered from the settlement site of Kabbashi Haitah situated on the east bank of the Nile River in the Central Sudan (Fig. 1; Caneva, 1993: 183; Magid, A., forth- 
coming; Magid, and I. Caneva, 1998: 80). Radiocarbon dates (of 7700 to 7200 bp) obtianed from the site and recovery of Early Khartoum types of lithic artefacts and pottery including its characteristic wavy-lines ware (Fig 2a) place the site within the Early Khartoum tradition which existed in the Central during the Early Holocene (Caneva, 1993: 183; Magid, and I. tradCaneva. 1998). Coincidentally, the plant impressions were found in two wavy line potsherds (Fig 2b). Methods and techniques of making positive casts (Magid, 1989; Magid, and Krzywinski, 1995: 121-132) were used to make positive replicas of impressions of the two seeds. The positive casts were identified as being seeds of naturally/spontaneously growing castor plant, Ricinus communis $L$. (Magid. A., forthcoming; Fig 3a and Fig 3b). This identification was drawn on the basis of comparisons with extant reference collection of seeds of castor plant (Fig 4a)

Since the two impressions of seeds of castor plant, Ricinus communis L. were found in mineral- tempered Early Khartoum type of pottery (Fig 2a; Francaviglia and Palmieri. 1983: pp. 192, 198-204; Magid, A. and I. Caneva. 1998: pp.85$86)$, there is reason to suggest that these findings are contemporary with the Early Khartoum culture-context in which they were found, hence they can also be dated to $7700-7200 \mathrm{bp}$. Accordingly, they represent the earliest evidence of castor plant, Ricinus communis L. to be found in the Sudan and elsewhere in Africa (Magid, A., forthcoming).

\section{Implications of the evidence}

The evidence of naturally growing castor plant $R$. communis L. from the site of Kabbashi Haitah represents the earliest documentation of this plant species in the Central Sudan (and Africa). Its recovery from this area raises many issues and questions and far reaching implications as being discussed in the following pages.

3.1 The origin of castor plant recovered from the Central Sudan.

This issue is best addressed by attempting to answer such questions as, whether the area of Central Sudan was a natural habitat for castor plant or was this plant imported from somewhere else? If imported, where did it come from and how? In order to answer these questions, we shall first study the botany and ecological requirements of naturally growing progenitors and compare these with the available data on the climatic, environmental and ecological conditions in the Central Sudan during the occupation of the site of Kabbashi Haitah 7700 to 7200 years ago.

\subsubsection{Botany and ecology of castor plant R. com-} munis L.

The botanical characteristics and ecological requirements of castor plant, $R$. communis L. inform about the ideal area (native habitat) for the natural growth of castor plant in ancient times, hence those characteristics can be employed as indicators in our attempt to draw an archaeological interpretation on the centre(s) of diversity and spread of this plant.

\subsubsection{Botany}

Naturally growing castor R. communis L. is an evergreen, tender and usually tall and fairly branched suckering tropical perennial shrub (Fig 4c) but it is not cold hardy plant (Andrews, 1952: 44-46; Al Amin, 1990: 140; Moldenke, and Moldenke. 1952: 203; Muschler, 1912: 595; Murty, and Subrahmanyam. 1989: 206; Weiss, 1971: 45; Zohary. 1982: 193). The plant produces many green (or immature reddish-green) alternate, palmately lobed and large leaves ( Fig 4c). The stems and 
branches of the cultivated ${ }^{*}$ varieties become hollow with maturity of the plant (Weiss, 1971: 56) and it has been stated that leaves of most cultivated" types "are often dark, frequently glossy green" (ibid: p. 57). If ingested, the fresh leaves may poison the body. The inflorescence are stout, erect, and pyramidal (Fig 4c). Flowers occur most of the year in dense terminal clusters ( http:// 2 and http:// 3) and are produced over an extended period and may continue all year when climatic conditions permit (Weiss, 1971: 63). It is cross-pollinated mainly by wind (ibid: 62). Each mature male flower bursts explosively as it dries and literally smokes as it shed its pollen in a gust of wind (ibid: p. 61; http:// 3). A mature fruit is globose and consists of spiny pod or capsule (c. $1.25-2.5 \mathrm{~cm}$ ) composed of carpels (or sections) and each carpel contains a single seed (Fig 4b; Al Amin, 1990: 140). At maturity, these carpels become dry, hard and brittle (; Weiss, 1971: 65) and each splits open (i.e. shatter) along its dorsal suture (outside seam) with such mechanism that the seeds are ejected with considerable force, often, with exploding sound making the seeds often fly in the air and bounce on the ground away from the mother plant (Fig 4b; ibid.; Murty, and Subrahmanyam, 1989: 206; Zohary, M. 1982: 193; http:// 3). Unless properly stored, the seeds do not generally store well for long periods of time (http://1)*** because the testa (the exterior layer) of the seed is fairly thin. The ripening of the capsules (fruits) extends over a period of time
(Weiss, E. A. 1971: p. 66). Similar to cultivation of wild cereals, seeds from non-shattering capsules are selected for starting a cultivated (and eventually domesticated) gene pool with uniform maturity period. The seeds are flattened-oblong (oval or egged-shaped), with smooth testa, generally mottled or streaked with various attractive colours, e.g. light and dark brown or black (Fig 4a) and their size varies from "a few millimetres long to nearly 2 centimetres in giant varieties" (Weiss, E. A. 1971: p. 66). At the (proximal) end of the seed there is a small spongy enlargement called the caruncle (Fig 4a) which helps in (reseeding by) absorption of water when the seed is buried in the ground (Land Protection. 2001: pp. 44-45; Moldenke, H.N. and A. L. Moldenke. 1952: p. 203; Murty, S. and N. S. Subrahmanyam. 1989: p.206). Over half of the seed- weight is attributed to oil held in special cellular organelles (Simpson, B. B. and M. Conner- Ogorzaly.2000: p. 324). Laboratory analysis showed that the seed contains laxative and purgative properties (ibid) but it is lethally poisonous to people, animals and insects. Eating a seed or two may cause nausea and intense stomach discomfort and eating several seeds can cause severe diarrhoea that might lead to death of the victim due to massive dehydration. Indeed, with the exception of the (cold pressed) oil from the seeds, all parts of the plant that contain sap are poisonous, and the sap itself is the most toxic. Even dried, some of this plant materials retain their poisonous properties but

\footnotetext{
* The context in which the verb cultivated is used (by E. A. Weiss :1971) is most likely meant to denote cultivation of domesticated castor. It is important in this work to distinguish between cultivation of wild and domesticated varieties of the same plant.

** See footnote no. 5.

*** It should be noted here that in addition to the standard referencing, some internet web sites (www) are also used in this work as sources of information. The sites used here are only those which have links to other sites bearing confirmatory information, hence, are believed to be both authentic. The sites are referred to as numbers preceded by http:// (e.g. $\mathrm{http}: / / 1)$. When reference is made to web-sites together with published/printed materials, names of authors of the latter are cited first followed by the web-site (e.g. Weiss, E.A. 1971; http://1). Full information on these web-sites is presented in their respective numerical sequence at the end the manuscript.
} 
the great concentration of toxin occurs mainly in the seeds (and their pods), which irresistible appearance (Fig 4a) makes them so dangerous (Grieve, M., http:// 2; http:// 5; http://6; http:// $7 ;)$. It is believed that if an undamaged seed is swallowed, it is most likely that it passes harmlessly through the digestive track (ibid.). It has also been reported that consumption of small amount of the plant material induces immunity against poison (Land Protection. 2001: 44-45). Although the castor plant has long been known for its toxicity, the ricin (pronounced rye-sin) was first isolated from the seeds and named in 1888 by H. Stillmark (http:// 9: http://10); an average of 0.2 milligram of ricin is considered to be twice as deadly as a cobra venom (http://10). If the oil is to be used for medicinal purposes, the seeds must be (cold) pressed at temperatures lower than $50^{\circ} \mathrm{C}$ so that the ricin is not removed with the cold drawn oil (Simpson, and Conner-Ogorzaly. 2000: 341). If properly stored, castor oil can stay unchanged for a long time because of its toxicity and high level of saturation (ibid.).

\subsubsection{Ecology and habitat}

Naturally/spontaneously growing castor $R$. communis L. grows and reproduce readily and successfully in moderately hot tropical climates, annual rainfall* of $375-500 \mathrm{~mm}$. well drained sandy or loamy soils (of medium texture) with adequate moisture and average fertility, clear sunny weather and long days (Land Protection. 2001: 44-45; Moldenke, and Moldenke. 1952: 203; Murty, and Subrahmanyam. 1989: 206; Weiss, 1971: 62, 123; Zohary, 1982: 193). As regards the optimum $\mathrm{pH}$, castor plant grows best in soils with low acidity (pH 5.0 to 6.0) and it also grows in heavy alkaline or saline clayey soil but at the expense (of both the rate and size) of its growth and productivity (Weiss, 1971: 117). Moreover, it can also grow in extremely fertile soils which enhance excessive vegetative growth but decrease seed yields (ibid: 123). High soil temperatures shorten the period from sowing to emergence of seedlings (ibid.: 111). Although it grows as annual plant, castor R. communis L. acts as perennial in tropical and semi-tropical areas (ibid: 64, 111) where conditions allow for prolonged growth. It is common and grows in abundance along water courses (e.g. banks of rivers, streams, gullies), as well as flood plains, disturbed and wasteland (ibid). The optimum temperatures for shedding the pollen are between c. $26^{\circ}$ and $29^{\circ} \mathrm{C}$ after sunrise and until late afternoon (Weiss, 1971: 61).

These ecological requirements most likely played a major role in assessing whether evidence of castor plant recovered from the Early Holocene site of Kabbashi Haitah was indigenous, imported, or cultivated in the area/region of the site. Inseparable from this assessment are the issues of origin and uses of the castor in the Early Holocene Central Sudan.

\subsubsection{Origin of castor plant recovered the site of} Kabbashi Haitah in the Central Sudan.

The cultural context coupled with the radiocarbon dates obtained from the Early Khartoum site of Kabbashi Haitah in the Central Sudan implicitly suggest that the archaeobotanical evidence of castor plant $R$. communis $L$. found the site (Magid, A., forthcoming):-

- represents the earliest known evidence of this plant , (7700 years bp) in the Central Sudan and Africa,

\footnotetext{
* Some botanists and plant ecologists suggest that (in order to produce the highest yields), a minimum rainfall of 600 to $750 \mathrm{~mm}$. is required (Weiss, E. A. 1971: p. 116). Obviously, these estimates are recommended for rain-fed cultivation of castor with the expectation of rewarding economic returns..
} 
-castor plant was naturally (spontaneously) growing in the area,

- the Central Sudan is one the earliest natural habitat of this plant.

These suggestions are based on the following facts:-

1- the archaeobotanical record from the region does not attest for the existence of earlier evidence of castor plant.

2- Palaeoclimatic research (e.g. Brewer, 1992; Hassan, 1998; Haynes, et al. 1989; Lario, et al. 1997; Williams, and Adamson. 1982), pollen analytical studies (e.g. Ibrahim, 1993; Khalafalla, 2002) and other archaeobotanical evidence recovered (Magid, 1982; 1989; 1995; 2003; Magid, and Caneva. 1998), indicate that the climatic conditions and the savannah type of ecosystem in the Central Sudan 7700 years bp. were conducive for the spontaneous growth of the plant (as they were at least five times wetter and richer than the prevailing conditions).

3- Material culture remains recovered from the site did not include evidence of imported goods or any indication of contacts with other region(s).

\subsection{Possible uses of castor plant by the early Ho-} locene population of the Central Sudan.

Taking into consideration the botanical and physiological characteristics of castor plant, R. communis L., it is possible that the prehistoric population of the site and the Central Sudan (Magid, A., forthcoming):-

1) used the colourful and attractive seeds of castor plant (Fig 4a and Fig 4b) for personal decoration.

2) used the tree-like plant of castor with its broad and dense leaves (Fig 4c) as a shelter and shade from heat and the sunlight.

3) observed the explosive dispersal mechanism of its seeds (Fig 4b) and the smoke-like shedding of its pollen which captured their interest and fascination and led them to express that in some forms of ceremonies/rituals.

\section{A survey positioning the evidence from the} Central Sudan within a world-wide context. In this section, archaeological evidence, classic sources, historic and ethno-historic studies on castor plant and its uses from both neighbouring areas and far away regions are examined and integrated in the present study. These are found to provide a comprehensive representation, hence the basis for a comparative study of early occurrences of castor plant and its uses since the Early Holocene period until modern times.

The discussion comprises a survey on some of the past and existing traditional uses of castor plant with emphasis on the following issues:-

1- Derivation and meaning of the plant-name(s)

2- the main theories on the origin and early centres of castor plant.

3- early (archaeobotanical, archaeological, textual, etc.) evidence of castor plant, its uses, and their spread in the World.

4- Assessment of continuity and discontinuity of different uses of the plant as seen in the traditional applications/uses of the plant in different parts of the World.

It is anticipated that the discussion on these issues will establish the value of inedible plants (as exemplified by castor plant) in different societies since Early Holocene and until modern times, hence confirm and motivate the importance of researching this type of plant remains. However, it should be noted here that naturalisation*, and cultivation of (spontaneously growing and domesticated) castor are issues beyond the scope of the present study. However, reference to these 
issues is made when it is thought relevant.

4.1 Derivation and meaning of the plant-names. Derivations and meanings of plant names (together with other archaeological evidence and historical sources) are often used as indicators when tracing the spread, migration and uses of the plants. Obviously, migration of plants from their natural habitat indicates movement of people from region to region for different purposes such as trade, search for pasture, etc.

Different names and meanings are given to castor plant at different periods of time in different parts of the World. The main emphasis here is on those old and common names and meanings which might provide some clues on the origin and spread of castor plant and its uses overtime. In addition, the discussion includes those names which are relatively younger but they communicate certain meaning (e.g. spiritual) or add new information.

To begin with, the current common and popular name of the plant "castor" seemed to have ensued from a mistake made by the eighteenth century English traders as they confused it with the name of the shrub Vitex agnus-castus which the Portuguese and Spanish in Jamaica called "agnus castus" or "agno casto" though it bears no resemblance to the South European plant properly called so (Weiss, A. E. 1971: p 6; Grieve, M. Grieve, M. http://2). Consequently, the name spread across the Atlantic by traders.

Taxonomically speaking, the castor plant belongs to the plant family Euphorbiaceae, genus Ricinus and species communis and hence, the binomial (scientific) name Ricinus communis L. When the scientific name Ricinus communis $L$. is coined in the eighteenth century, the castor plant was already naturalised in many parts of the world (http://4). This inventive term "Ricinus communis" is used to refer to the interesting form and markings of the seed of this plant. "Ricinus" is the Latin word for "tick" and "communis" is also a Latin word which means "common" to denote its common or wide distribution. In fact, the Greek physician Pedanius Dioscorides, c. in the first century and the Greek botanist Theophrastus referred to it as kroton which means the dogtick (Weiss. 1971: 5) because the shape of the mottled body of the tick resembles the body of the castor seed and the tick's head resembles the caruncle (i.e. spongy structure) at the proximal end of the seed (Fig 4a and Fig4 b; http://5; http://6). Other common synonyms are "ricin plant", castor oil plant (derived from the oil extracted from its seeds), Palma Christi or Palm Christ, African coffee tree, wonder plant, castor bean plant (http://3; http://7; http://8). With the exception of the name "Palma Christi", all the other names and terms of the plant (scientific and common alike) are relatively recent (being in use for the last three centuries) but they are well known and widely spread. Palma Christi "or the "Hand of Christ" is given to this plant in ancient Rome (http://9) and was thought to have been inspired from the shape of the leaves (Fig 4c). Obviously, the association of the plant with the Hand of Christ indicates some religious connotations.

One of the most ancient names of castor plant (we are aware of) is "kiki", "kikki"or "kaka" retrieved from ancient Egyptian treatise (Moldenke, and Moldenke. 1952: 203; Zohary, 1982: 193), namely the medical prescription (No. 201)

\footnotetext{
* In this paper, the terms "naturalisation" and "naturalised" are used to denote new area(s) to which plants were introduced and flourished and that the terms" origin" and "native" are used on grounds of their literal meaning denoting the source area(s) where castor is believed to have originated.
} 
contained in the Ebers* ${ }^{*}$ papyrus dating to 1552 BC (http://8; http://10). Referring to this medical treatise, both Herodotus ( Zohary, 1982: 193) and Strabo (Grieve, Grieve, http://2) stated that "kiki" was grown in Egypt for "kiki" oil (ibid). At the time when Herodutus wrote $\left(4^{\text {th }}\right.$ century $\left.B C\right)$, it seems that this plant has already been introduced in Greece (ibid). In fact, it was reported in a Greek papyri which date to the Graeco-Roman period, (c. 300 BC and A.D. 650) and found in the province of Fayum, where it was frequently referred to as "kiki" or "kroton" (Weiss,1971: 5). The original ancient Egyptian name "kiki" reappeared (though slightly changed to "kik") and used by some writers during the late $16^{\text {th }}$ century (Grieve, Grieve, http:// 2).

It has also been reported that castor plant is mentioned under several names in the ancient Indian Sanskrit ${ }^{* *}$, the most ancient and common one is "Eranda" (ibid) dating back to 2000 BC (Weiss, 1971: 7; http//11) . To our best knowledge, this is one of the earliest textual sources on the castor plant. Theophrastus referred to the Greek name of castor kroton (Sir Hort, 1948: 69, 71) and Dioscorides (in the first century) described the plant and its different uses (Grieve, Grieve, http://2). The Hebrew word "יקייון asiquayon,

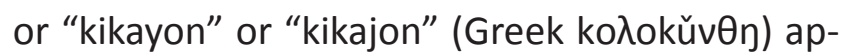
peared in the Bible (in passage, Jonah 4: 6-7) and is rendered differently in different translations (Moldenke, and Moldenke, 1952: 203; Weiss, 1971: 5; Zohary, 1982: 193). However, there are marginal notes in both the Authorised and Revised versions which translate it as Palma Christi or Palm Christ (Moldenke, and Moldenke. 1952: 203). If this translation is accurate, it remains to be linguistically proven whether the Hebrew name "kikajon" or "qiqayon" is derived from or related to the ancient Egyptian kiki. Nonetheless, being called Palma Christi and appearing in the Bible, this plant has probably some religious association.

To sum up, the foregoing general survey shows that by 4000 bp castor plant was known in different parts of the Old World and that some of its ancient names travelled long distances and continued to be used for thousands of years not only where these names originated but also in other parts of the World, for instance, the ancient Egypt name kikki continued to be used until the $16^{\text {th }}$ century in different parts of Europe. However, this may also lead one to ask about the origin of the Egyptian "kikki" (as it shall be discussed in the following pages).

4.2 Theories on the origin(s) and Early Centres of castor plant

Castor oil, R. communis L. was well known and has become naturalised in tropical and warm temperate regions throughout the World since ancient times (Weiss, 1971: 3). It is so ancient that there is no agreement among researchers about the centre of diversity (native area) of the castor plant $R$. communis L. By the time it was domesticated, it appeared to have spread across Africa and Southern Asia (Simpson, and Conner-Ogorzaly. 2000: 341, Weiss, 1971: 3). However, there are at least two continents, namely Africa and Asia, that are generally believed to be the centres of diversity of castor plant. But, differences do occur as regards (i) which of the two is the continent of origin, and (ii) where in the continent (i.e. region, part,) are the early centres of castor plant.

\footnotetext{
* In 1872, George Ebers translated an ancient Egyptian medical treatise and given the No. 201.

** Sanskrit (n.) is the ancient version of the Hindu, the language of the Vedas (Weiss, E.A. 1971: p. 7) but preserved to the present day as the literary and sacred dialect of India (Webster's Dictionary. 1913).
} 


\subsubsection{Theories on Early Centres of castor plant}

There is a vague yet revealing theory which suggests that "castor plant is, in the main, a tropical plant of unknown origin" (Zohary, 1982: 193). If this theory is combined with the climatic conditions and ecological requirements for the optimum growth of naturally growing stands of castor plant, the broad unknown tropical origin could now be narrowed down to either tropical Africa, tropical Asia or both. In fact, several theories have been proposed as regards its origin in either or both of these tropical regions. These can be summarised as follows:

\subsubsection{The African origin}

Some researchers (e.g. Muschler, 1912: 599; Murty, and Subrahmanyam. 1989: 205) suggest an African origin for the castor plant R. communis L. without stipulating which area or geographical region. There is another group of researchers who also suggests that castor plant is of an African origin and added that its origin is unknown (http://7). A third (widely received) suggestion embraced a Tropical African origin of castor (Purseglove, 1976: 294; http:// 9) and proposed further that naturally growing castor plant occurs in various parts of Eastern Tropical Africa (Purseglove, 1976: 294; http:// 14). Some of those researchers who support the Eastern Tropical African origin are more specific as they named Ethiopia or the Ethiopian region of Eastern Tropical Africa as being the land of origin of castor plant (David, 1976: 252; Purseglove, 1976: 294; Shaw; 1976: 113,133; Weiss. 1971: 3, 45; http://3; http://5; http://7; http://11; http://13). Evidently, the Central Sudan is comfortably placed within both the Tropical African and the
Eastern Tropical African regions. Consequently, the theory of an Eastern African Tropical origin is now substantiated for the first time with archaeobotanical evidence of castor, which dates back to $7700 \mathrm{bp}$. The present writer is not aware of earlier evidence from this region or elsewhere in the World.

\subsubsection{The Asian Origin.}

Some scholars suggest an Asian origin of castor plant (Moldenke, and Moldenke, 1952: 204), but no region or area is specified. Other sources are more conclusive for they suggest that the subcontinent of India is the land of this plant (Murty, and Subrahmanyam. 1989: 205; Grieve, http://2; http://11). Some of the latter group cited some linguistic evidence (ancient Sanskrit) dated to 2000 BC which indicates that castor plant occurred in the Vedas* in India (Weiss, 1971: 7; http://11).

\subsubsection{The African-Asian Origin: (Continental} Pairing).

Some authorities advocate a theory of an African and Asian origin (Land Protection. 2001: pp.44-45; Murty, and Subrahmanyam 1989: 205; http://13). Other more specific researchers apply the theory of continental pairing to account for the early occurrence of castor plant in both India and the Ethiopian region (Weiss, 1971: 7) but no dates were provided.

With the exception of the theory of the East African Tropical origin; which is now substantiated with direct botanical evidence of castor plant from the Central Sudan, the other theories are derived on the basis on indirect fragmentary, circumstantial and linguistic evidence (Weiss,1971:3).

\footnotetext{
* Veda (n.) is any, some or all of the four collections (Rig-Veda, Sama-Veda, Yajur-Veda and Atharva-Veda) of the ancient sacred literature (writings) of the Hindus (Webster's Dictionary: 1913).
} 
4.3 Early (archaeobotanical, archaeological, textual, etc.) evidence of castor plant, its uses, and spread: Examples from different parts of the World.

The main emphasis in this section is on the early direct (botanical) evidence of castor plant as well as ancient texts and inscriptions, classic sources and historical records that document and/or refer to early occurrences of this plant species and its uses in different parts of the World.

\subsubsection{African countries: Sudan and Egypt.}

In Sudan, several seeds of wild castor R. communis L. were found in a bronze object identified as being a saltcellar excavated from grave (no. 177) in an ancient cemetery near the village of Abri in North Sudan and dated to c. $100-70$ BC (Fernández, 1984: 43, 82). It was interpreted as being used for keeping (dry and fresh) foodmaterial intact (Fernandez, : personal communication). As castor seeds are poisonous, it is unlikely that they were mixed with food materials. If the castor seeds are damaged, their content is poisonous, hence, it is unlikely that those seeds were mixed with food materials. In addition, the size of the saltcellar is too small to be used for keeping food materials. Thus, since the castor seeds were found in this saltcellar-like object, it was most probably used to extract oil from castor seeds by heating then separating the oil from the seeds-residue through the holes at the top of the cellar. The oil drawn was most likely used for lighting. Since the saltcellar was found in a grave, it is most likely that it served some symbolic or ritualistic purposes.

As regards Egypt, seeds of castor plant $R$. communis L.and grains of wheat and barley have been were found in pottery vessels in the Badri region near Sohag in Egypt and dated to the Badarian (ca. 4400-4000 BC); a pre-dynastic cul- ture (Hendrickx, and Vermeersch. 2002; MidantReynes. 1992: 160). Arkell and Ucko (1965: 150) stated that those castor seeds are probably wild (undomesticated) but did not specify (i) how they concluded that those seeds were "wild" and (ii) whether they were locally growing or imported. The present writer suggests that if the seeds are proven to be "wild" then they were most likely imported as the climatic and ecological conditions were unfavourable for the natural growth of the plant. ( Purseglove .1976: 299 and Zohary 1982: 193) suggested that castor plant was cultivated in ancient Egypt. They also reported the finding of seeds in Egyptian tombs dating to 4000 BC. which were most likely Badarian tombs as this culture is mainly known from cemeteries dating to $3^{\text {rd }}$ millennia BC. Neither Purseglove nor Zohary specified whether the cultivated castor was wild or domesticated. Nevertheless, this evidence is considered one of the earliest attestations of agriculture in Upper Egypt. The aspect of a Badarian agriculture is supported by the finding of botanical evidence of grains of wheat, Triticum dicocum and barley Hordeum vulgare as well as evidence of sickles (Midant-Reynes, 1992: 160). One of the earliest authentic records of Temple Garden collections which contain specimens of the castor plant, is also dated to the reign of Thutmosis III, c. 1500 B.C. (Weiss, 1971: 4). It was suggested that castor plant was probably domesticated in the Fertile Crescent of Asia minor and in the Nile Basin (ibid. : 3).

The ancient Egyptian medicinal treatise (No. 201) which is believed to be dated to 1552 BC. and contained in the Ebers papyrus (http://10) clearly shows that ancient Egyptians were familiar with the pharmaceutical content and medicinal value of the castor oil. It describes (among others) different parts of the castor plant being used by ancient Egyptian for a number of medical appli- 
cations (ibid.). Among these, emphasis is made here on those which seem to have continued to be used until modern times as demonstrated in the following examples.

It should be emphasised that the ancient Egyptians conceived sickness and health as a continuous fight between evil and good. Therefore, those involved in the medical and pharmaceutical practises used to recite certain incantations while preparing or administering medications (http:// 5; http:// 9).

In addition to the curative applications presented above, the ancient Egyptians used castor plant for other domestic and cosmetic purposes as presented in table (1).

1- Classic and historical sources revealed that ancient Egyptians used castor oil in wick lamps for lighting (Simpson, and M. Conner-Ogorzaly. 2000: 341; Weiss, 1971: 4; http:// 3). Both Herodotus (in the $4^{\text {th }}$ century BC), and Strabo (c. in the $1^{\text {st }}$ century) used the ancient Egyptian word kiki (referring to castor) when they reported that it was a product of Egypt and the oil of which is used for lighting lamps (Weiss, 1971: 4; http://5). Dioscorides and Pliny (in the $1^{\text {st }}$ century) also stated that ancient Egyptians used castor oil for lighting (Quer, P.F. 1985: p. 188; Weiss, 1971: 4).

2- The medical treatise No. 201 reported that a lump of ground and kneaded castor fruits soaked in oil can be applied to women's hair to help it grow (http://10). It has also been used externally as unguents to soften the skin (Grieve, http://2). 3- Sections of hollow castor stems were used by highborn ladies (during the Eighteenth Egyptian Dynasty, 1567 - 1320 BC) to store kohl (Weiss, 1971: 4). This implicitly shows that, 3000 years after it was first cultivated in Egypt, castor was still valued as a rare and precious plant. Accordingly, one may assume that the plant was not naturally growing. Since a hollow stem is considered one of the criteria of domesticated castor plant (ibid.: $56)$, this means that by the time of the Egyptian $18^{\text {th }}$ Dynasty (if not earlier), cultivated castor plant belonged to domesticated species.

4- Castor plant,( mainly seed-oil) was also used as libation in certain religious ceremonies (Simpson, and Conner-Ogorzaly. 1995: 341; Weiss, 1971: 4). It was suggested that the seeds found in the ancient Egyptian sarcophagi were meant to accompany the dead on their journey through the "Land of Shades" and was also used in rituals of sacrifice to please the gods (ibid.) and further testify the special value of this plant.

\subsubsection{Asian countries: India, China and Persia.}

The earliest reference to castor (as being a plant of India) and to its oil is made under several names in the ancient Indian Sanskrit in the Susru-

table (1)

\begin{tabular}{|c|c|c|}
\hline Reason for use & Preparation & Application \\
\hline Mal-digestion \& constipation & $\begin{array}{c}\text { 1. castor oil. } \\
\text { 2. castor oil combined with figs \& dates. }\end{array}$ & internal use as laxative (purgative). \\
\hline Headache & $\begin{array}{c}\text { 1.Soaking roots of castor in water until } \\
\text { they dissolve. }\end{array}$ & applied to the head. \\
\hline $\begin{array}{c}\text { Stimulation/induction of } \\
\text { labour }\end{array}$ & castor oil. & external application. \\
\hline Eye irritation & castor oil & $\begin{array}{c}\text { rubbing the oil round the eyes } \\
\text { (http://9). }\end{array}$ \\
\hline $\begin{array}{c}\text { Cleanse the body \& preserve } \\
\text { health, }\end{array}$ & $\begin{array}{c}\text { purge the body with kiki (castor oil) for } \\
\text { three days every month. }\end{array}$ & $\begin{array}{c}\text { external application (reported by } \\
\text { Herodotus in } 500 \mathrm{BC} \text { (http://5). }\end{array}$ \\
\hline
\end{tabular}


ta Ayurveda*, dated to 2000 BC and the most ancient and common of these is said to be "Eranda" (Murty, S. and N. S. Subrahmanyam. 1989: p. 205; Weiss, 1971: 7). Others argue that the cultivation of castor and the use of its oil are so well established that the origins of this plant are lost in time (Weiss, 1971: 7). However, we are not aware of any source or evidence which named the region of origin or suggested the initial area(s) of its domestication in India.

The earliest direct (botanical) evidence of castor plant, known to us from India, was recovered from the site of Ter in the middle Southwest of the Indian sub-continent (Kajale, 1991: 159). The site is dated to the Satavana and Indo-Roman period, c. 200 BC. - AD 200 (ibid.: 176) but the status of the evidence (i.e. naturally growing or domesticated) was not specified. In this connection, it is noteworthy that the earliest reference to castor plant at $2000 \mathrm{BC}$ coincides with the earliest direct evidence of domesticated Sorghum sp. Moench, recovered from the site of Daimabad, c. $250 \mathrm{~km}$ northwest of the site of Ter (ibid: 174). The evidence of Sorghum sp. was interpreted as being of an African origin (ibid.: 175) but the climatic conditions and the cultural practises in the rainfed western part of India suited its cultivation (ibid.: 174). On one hand, there is no authentic botanical evidence of domesticated sorghum in Africa which dates back to 2000 BC. On the other hand, no evidence of naturally growing race(s) of this plant is found in India in 2000 BC to indicate that this region was a natural habitat of the early races of naturally growing Sorghum. Thus, there are compelling reasons to suggest that sorghum domestication was first initiated in India in isolation of its naturally growing progenitor c. 4000 years ago. The earliest botanical evidence of naturally growing sorghum was recovered from several Early and Middle Holocene sites in the Central Sudan (Fig 1; Magid, 1995, 2004; Magid, and, Caneva. 1998). Coincidentally, one of these sites is the site of Kabbashi Haitah from which evidence of castor plant was also recovered. Thus, the same elements (i.e. dates, geographical area, climate ecological conditions) on which basis evidence of Sorghum sp. in India was interpreted as being of an African origin, are also applicable as regards the explanation of the origin of castor. For instance, similar to sorghum, castor plant, R. communis L. is an indigenous Tropical African plant which was most likely brought from Africa to India in the $2^{\text {nd }}$ millennium BC where it was grown. This hypothesis may be used to (i) to acquire archaeoboatnical evidence, hence verify further the early dates for the presence of castor plant in India, and (ii) identify the status of the early evidence of castor (i.e. wild or domesticated).

Similar to its use in ancient Egypt, castor oil was also used in ancient India as laxative, (e.g. as described in the Vedas dating back to 2000 BC.) and for lighting lamps (http://5; http://11) and that it bears several ancient Sanskrit names, the most ancient and common are Eranda and Ruvuka (Weiss, 1971: 8; Grieve, http://2; http://5). It was also used for treating dry and hard skin. In addition, it was used for repelling insects and was also placed round hut foundations and trees as termites-deterrent (Weiss, 1971: 7).

The use of castor oil in medicinal and remedial applications mentioned above is said to be well documented in the Indian Charaka-Sumhita dated to c. AD 100 and the Susruta-Samhita dated to

\footnotetext{
* Susruta Ayurveda is an Indian holistic system of medicine and health of the Vedas preventing and treating diseases as well as providing optimal health and happiness (Murty, S. and N. S. Subrahmanyam. 1989: p. 205; Weiss, E., A. 1971: p. 7).
} 
c. 200 BC (Weiss, E. A. 1971: p. 7).

Historical records show that in addition to its being used as laxative since ancient times, castor oil was also used in India (as well as China) for induction of childbirth and the expulsion of the placenta (http:// 9). It has also been used in China in medical dressings and the Persians are reported to have used it for treating epilepsy (ibid.). Although the Chinese seem to have long used castor oil for medicinal purposes, the earliest mention of castor in Chinese literature dates to the T'ang period (A.D. 618 - 906) where it was referred to as a cultivated plant (Weiss, E. A. 1971: p.8). It has been suggested that it was probably introduced to China (as were many other plants) via the Silk Road or through Kashmir with the saffron trade (ibid.). It is also believed that since early in recorded history, castor oil was one of the trade items with Central Asian tribes, especially the nomadic ones who used it in order to soften and preserve leather and leather products (ibid.).

\subsubsection{Arabian Peninsula and the Fertile Crescent} In Arabia, the nomadic tribes administered castor oil internally in order to cleanse themselves and their animals (Weiss, 1971: 5). They also used it externally to treat skin conditions and to relief rheumatic pain. Researchers are in disagreement as to whether castor plant was introduced to Arabia from Africa or India. William Dymock (1893: 302), the author of the "Pharmacographia Indica", maintains that it was imported from India, as one of the Arabic names for castor is "Simsimel-hindi", [Eng. Indian sesame] (ibid) . Other Arabic names are Khirwa'(خبروع) ) and Kharrub (خربوب). It was also stated that the Arabs used it as described by the authors of the Sanskrit in order to remain healthy (ibid.; http://7).

In addition to the different medicinal applica- tions of castor plant and the use of its seed-oil for lighting lamps, it was also used in some religious ceremonies; e.g., castor oil was used extensively by the Hebrews in their religious functions (Moldenke, and Moldenke. 1952: 203-204) and it is mentioned among "the five kinds of oil which rabbinical tradition sanctions for such use" (ibid.). "God caused this "kikajon" plant to grow and provide shade and shelter for Jonah when he sat outside the City of Nineveh, c 750 BC" (Moldenke, and Moldenke. 1952: 203; Weiss, 1971: 5; Zohary, 1982: 193).

In addition to its religious association (as discussed above), it has also been reported that castor oil was used in witchcraft (voodoo) ceremonies (Weiss, 1971: 6). Even the extraction of castor oil (in some parts of the World) was made by certain people due to some superstitions and taboos. For instance, certain tribes in Malawi use castor oil which was extracted by women who passed the childbearing age (Weiss, 1971: 6). If childbearing women extract the oil, it is believed that the oil produced would cause a certain disease (ibid.). More examples on taboos, superstitious, and religious uses of castor are presented in the work of E. A. Weiss (1971) on castor plant, $R$. communis $\mathrm{L}$.

4.3.4 European countries: Greece and the Roman Empire

When Herodotus wrote (in the $4^{\text {th }}$ century BC) about some of the uses of castor oil in ancient Egypt, it seems that castor plant has already been introduced to Greece where it is cultivated (even today) under the same ancient name (Grieve, M. http://2). Pliny also wrote about castor as purgative (Weiss, 1971: 5; http://8). Dioscorides (Quer, 1985: 188) and Theophrastus (Sir Hort, 1948: 69, 71) assembled some of the early botanical descriptions of castor plant. Dioscorides went fur- 
ther describing the process of extracting oil from its seeds and asserted its unsuitability as food but established its usefulness for many other purposes especially as remedy for a number of diseases (Quer, P.F. 1985: pp. 188-189). He explained that, as a drink, castor oil cures diseases such as cholera and constipation and it can also be used as drops to treat eye inflammation. He added that pure castor oil or oil mixed with vinegar can be rubbed on the nipples and breasts of pregnant women (during the last period of pregnancy) in order to soften them and ease the pain they create. He also stated that the oil is rubbed on the bladder area to kill stomach worms and that a paste made from the seeds could be rubbed on the skin in order to remove skin-stains, and cure sunburns, skin abrasion and external wounds (ibid.).

By the time of the Roman Empire, castor plant was established in Eastern Europe and was believed to have been introduced from the ancient Egyptians or the Persian empires (Weiss, 1971:6). The Greek papyri (mentioned earlier) frequently referred to the oil, seeds, leaves and roots of castor plant (ibid: p. 5). Thus, it is most likely that the ancient Greek and Romans copied the ancient Egyptian practise of regular cleansing of the body with castor oil in order to remain healthy (http://7). This practise was widespread until a medieval Arabian physician and masseur (called Jahian Ebben Masawaih) promoted the use of another ancient Egyptian remedy for constipation, namely the milder laxative senna, Cassia sp. (ibid.).

During the early Middle Ages, castor oil has also been cultivated and widely used for medicinal purposes, mainly skin diseases. It was also well known as a garden plant in England in the mid $16^{\text {th }}$ century (Grieve, Grieve, http://2). Gerard, a West European writer of the late $16^{\text {th }}$ century, was one of those who were familiar with castor plant under the name kik. He stated that its oil was used externally to treat skin diseases (ibid.). This name (i.e. kik) was probably derived from the ancient Egyptian name "kiki". In fact, it was reported that the monks of the Middle Ages (who were skilled in the art of healing) copied manuscripts and important medical treatises of physicians and medical writers such as those written by Dioscorides and Pliny the Elder (Telesko, 2001:8). These historical facts strongly indicate that names of medicinal plants such as kiki, pharmaceutical formulas and medical prescriptions were both preserved and continued to be used in the same manner as those copied from ancient treatises. At a later period (mainly the $18^{\text {th }}$ century) castor plant was no longer cultivated in Europe and the supplies needed for medicinal purposes were imported from Jamaica (Grieve, M., Grieve, M. http:// 2).

\subsubsection{The Americas}

When it was first introduced to the Americas, castor plant was mainly used in medicinal purposes (ibid.). The Maroons* used castor oil mostly as laxative but it was also used as a cleanser (e.g. from colds) and midwives used it to speed up labour. On the basis of these historical facts, it seems reasonable to suggest that African slaves introduced both castor plant and its traditional healing prescriptions to the Americas. Weiss suggests it was "transferred with" (and not brought by) the slaves to the New World (Weiss, 1971: 9). A physician who travelled in the West Indies dur-

\footnotetext{
* Maroon is a name used since 1530 for African-American runaway slaves. The last of these Maroons died in Cuba 25 years ago (http://14).
} 
ing the mid of the $18^{\text {th }}$ century reported that people used castor oil for several purposes including remedial application to cool or calm delirious fevers (ibid: p. 6). Gardeners in U.S.A. believe that castor plant help to rebel moles, thus, they grew it round their gardens. Farmers in the most Southern districts believed that it prevented malaria by keeping away mosquitoes (ibid.: p. 9).

\subsection{Ancient methods of extraction of castor oil} One of the earliest methods of extraction of castor-oil is based on grinding (mainly by grinding stones) to crush the tissue of the seeds and release the oil (Simpson, and Conner-Ogorzaly. 2000: 341). The crushed mass was often suspended in a cloth bag that allowed the oil to seep through into a container. Other ancient tools and method include mortars and pestles, often with a deep inverted cone and a revolving pestle, and a press with a wedge that was manually pounded (ibid.). Herodotus reported that in order to obtain oil, castor seeds were bruised and pressed or roasted and boiled (Weiss, 1971: 4). Pliny wrote that neither fire nor water were used to extract the oil but the seeds were first sprinkled with salt then pressed (ibid.: 4). Dioscorides described another method in which the oil was extracted by grinding the seeds in a mill and the ground mass was put in a basket and pressed (ibid.). Most of the methods of oil extraction (especially those which include direct heating or generate heat of more than $50 \circ \mathrm{C}$ while crushing and processing the seeds), would have produced oil largely mixed with lethal poison. Thus, future research on ancient/ traditional methods of extraction of castor should address the following questions:-

1- what procedures did the past societies used in order to produce and/or distinguish between the poisonous and poison free-oil?

2- how did they administer the precise medicinal doze used, e.g., as purge? and

3- how did they control production of proper quality of oil and avoided oil types and volumes which could be harmful or fatal?

In summary, the foregoing account on the early evidence of castor plant and its uses shows that:

1. different parts of castor plant, R. communis L. and bi-products (including oil) were used for almost the same purposes at different times in different parts of the World.

2. castor oil was the most used element of this plant for various purposes ranging from a number remedial preventative applications, to lighting and cosmetic purposes.

3. Different methods were used for extracting the oil from the seeds.

4. the extensive use of oil in ancient times, to say the least, indicates:

a. the importance and impact of this plant species in the lives of ancient societies,

b. a high degree of both knowledge and technology for extracting and administering castor oil for medicinal purposes.

4.5 Indigenous/traditional knowledge and practises pertaining to traditional uses of castor plant. 4.5.1 Definition of terms: Indigenous and Traditional.

In international context, the term indigenous is viewed as a synonym of traditional (Loubser, 2005) from that perspective of an inherited pattern of thought/belief, customs and practises followed by a people from generation to generation. Indigenous/traditional knowledge is "a total sum of knowledge and skills constitutive of [people] meaning, belief systems and dynamic livelihood construction" (Mazonde, 2010). It is "informed by and relates to all domains of life and the environment" (Magid, 2011: 137). Accordingly, one can safely suggest that indigenous /traditional knowl- 
edge is mainly derived from and built on cumulative experience and practises passed from the old to young generation, hence it is dynamic and continuously developing (ibid.).

\subsubsection{Traditional /indigenous uses of castor plant.} Indigenous / traditional uses of castor plant $R$. communis L. are still widespread in different parts of the World. Similar to its uses in the remote and recent past, different parts of this plant, e.g. seeds, seeds-oil, leaves, roots, stems, and fibres are traditionally used to serve different purposes. As previously stated, the main emphasis in this section is on some of the most common and widespread uses which are thought to have their roots in the past or that they represent a modified version of ancient uses of castor plant. Different traditional methods are still used to extract oil from the seeds of castor plant. The most common of those methods are the manual (labour-intensive) and animal-driven seed-pressing techniques (Simpson, and Conner-Ogorzaly 2000: 341). But there are also other methods which seem to have their roots in the ancient Egyptian period some 6000 years ago (Weiss, 1971:4). For instance, the ancient method described by $\mathrm{Di}$ oscorides (and presented earlier in this paper) continued to be used in Egypt and India until modern times (ibid: 4-5) and another ancient method described by Herodotus (also outlined in the foregoing discussion) was used by some tribes in Malawi until bottled oil was introduced (ibid.: 7).

All the traditional/indigenous utilizations of different parts of castor plant can generally be divided into two broad categories, namely medicinal applications, and non-medicinal uses.

\subsubsection{Traditional/indigenous medicinal applica-} tions.
Medicinal applications can be further divided into two general sub-divisions; namely, remedial applications and inductive, preventive and protective applications.

\subsection{Recipes and remedies.}

Simple and complex preparations made from different parts of the castor plant are administered externally and/or internally to cleanse, heal, or cure many diseases and symptoms as explained in the following examples.

1- Castor oil is internally administered in different parts of the World as laxative for treatment of constipation, or to clear the digestive tract in cases of poisoning (Moerman, 1986: 409, Weiss, 1971: 7; http://5; http://7). Its use as laxative continued, without change since the ancient Egyptian times, some $6000 \mathrm{bp}$. Similar to another ancient Egyptian remedy, castor oil is also traditionally used to treat headache but there are some differences as regards its application. While the ancient Egyptians used it externally (by rubbing it on the head), some of the traditional remedies recommend chewing of a few seeds of castor (Moerman, 1986: 409). Castor oil is also administered internally to treat ringworms and tape-worms (http://15). It is also administered internally to treat intestinal inflammation, diarrhoea and dysentery. Other traditional remedies which continued since times immemorial include external use of castor oil to help healing abscesses, sores, itches, skin-irritation and infections (http://15).

2- Castor leaves (often steamed) are used externally to relieve pains caused by injuries, bruises, stiffness, back-problems, rheumatism and arthritis and to cure headaches (Weiss, 1971: 7). Castor leaves are also softened by heat and applied externally to cure boils and swellings and to extract worms (ibid.). The present writer witnessed 
traditional healers in Atbara area in North Sudan and the Ingassana Mountains in South-east Sudan cured abscesses by applying externally pounded leaves bandaged with fresh ones on the abscess repeatedly until they were completely healed and dried up without any side-effects. It has also been reported from other parts of Sudan that fresh leaves are applied to swollen parts of the body and are kept there until they dry up (EI Safi, 52)

3-A decoction of pounded and boiled castor roots is applied externally for treatment of rheumatism or gouty swellings (http://15).

\subsection{Preventive and protective applications.} Prescriptions made from different parts of castor plant have been and still are used in different parts of the World for inductive, preventive and protective applications such as:

1- Castor seeds are considered an effective traditional catalyst for birth control (Moerman,1986: 406; http://11); one castor seed (chewed or swallowed) after the menstrual cycle prevents the woman conceive that month (ibid.). But large doses of castor seed-oil used as purgative during early pregnancy may cause abortion (Balick, and Cox. 1997: 45).

2- One of the traditional uses, which can be traced back to dynastic Egypt, is the use of castor oil to initiate or induce labour (http://3; http://9) by administering it externally in order to stimulate the uterus, soften the cervix and help induce labour (http://9). Some midwives rub the oil on the belly and feet of the pregnant woman to stimulate labour (http//9; http://15). It has also been stated that castor oil is also used externally to promote the healing of the umbilicus cord in newly born babies and rubbed on their skins to prevent itches, skin irritation and infection (Weiss, E. A. 1971: p.7; http:// 9). It is also reported that hair-wash with castor oil is used as a folk recipe for protection from or removal of dandruff, lice, fleas and other scalp problems (http://15).

3- Poultice Castor leaves (sometimes boiled) or castor oil-massage are applied to the nipples and breasts of lactating mothers (shortly after childbirth) in order to stimulate the mammary gland, hence produce or increase milk flow (Balick, and Cox 1997: 45; http://9; http://11; http://15).

The foregoing account on the remedial and other related uses of castor plant and its oil show that different parts of the plant are used for different purposes or that the same part of the plant, e.g. leaves, can be used for different remedies. Similar to the ancient traditions, castor oil is the most common and widely used both for treatment of various diseases and as a preventive/protective agent.

\subsection{Other traditional uses of castor plant} Different parts of castor plant are also used for purposes other than medicinal applications. These can be divided into two broad groups, namely, utilities and body care as demonstrated in table(2).

\subsection{Utilities.}

\subsection{Body-care.}

1. Many societies in different parts of the World use castor oil as ointment to soften hard and/or dry skin or retain its soft texture and maintain healthy physical appearance. It is rubbed on (i) the hands and feet before going to bed in order to keep them soft (ii) the body before bathing to keep it healthy and relax the muscles and imparts sound sleep (http://11) and (iii) the eyebrows and eyelashes or on the pimples to keep them well-groomed. Tribesmen in East Africa use it to anoint their skins (Weiss, 1971: 6).

2. Castor oil is also used for prevention and/or 
removal of dandruff, and it is also regularly used mainly by females (e.g. in East Africa and India) as tonic to help the growth of hair (ibid.: pp. 6,7), strengthen it and retain healthy appearance/exposure. Traditional applications of oil to the hair can be traced back to c. 6000 ago in ancient Egypt (ibid;), however, with slightly different recipe; while the traditional recipe consists of pure castor oil, the ancient Egyptian recipe consisted of ground and kneaded castor-fruits soaked in oil (http://10).

3. The colourful and attractive seeds are often seen in jewellery in some parts of the World (http://4; http://12); e.g. the Caribbean castor seeds- necklaces (http://12).

\subsection{Other uses}

1. Some communities hold mythical beliefs in castor plant (http://15). For instance, in West

Africa the local people believe that it protects them from lighting and call it the "thunder tree" (ibid.). Some African witch doctors use collections of colourful seeds "as part of their impedimenta" (Weiss, 1971: 6) to heal or bewitch people. Others use them as fortune teller and in the West Indies castor oil is still used in some voodoo ceremonies (ibid.).

2. The seeds are also used in entertainment games (Weiss, 1971: 6).

3. As castor is an imposing plant that adds exotic flair to the landscape, it is often grown for ornamental effect of house-gardens.

The foregoing general survey on the traditional uses and applications of castor plant clearly reflects both a large degree of continuity and spread of its uses over time often without significant change of the original (or ancient) recipes, formulas and applications.

\section{Concluding summary.}

The foregoing account on castor plant draws attention to the following main points:

table(2)

\begin{tabular}{|c|c|c|}
\hline Part of the plant used & Preparation & Purpose \\
\hline Fibre extracted from the stem & $\begin{array}{l}\text { Extracted by traditional pound- } \\
\text { ing method }\end{array}$ & To make ropes ((http://7; http://15). \\
\hline long and short branches \& stems & No preparation & $\begin{array}{l}\text { for hut building, e.g in Uganada, (Weiss, E.A. } \\
\text { 1971: p. 6). }\end{array}$ \\
\hline dry stalks \& stems & No preparation & firewood (ibid.: p. 9). \\
\hline castor oil & Pressing the seeds & $\begin{array}{l}\text { fuel for domestic lighting, e.g. in India (where its } \\
\text { ancient name 'Eranda' is still used), and in Java } \\
\text { and Africa (ibid.: p. 8). }\end{array}$ \\
\hline castor oil & Pressing the seeds & leather tanning (ibid.; Grieve, M. http://2). \\
\hline castor leaves & $\begin{array}{l}\text { reaped, dried \& stored, to } \\
\text { be cooked in boiling water in } \\
\text { winter. }\end{array}$ & $\begin{array}{l}\text { To feed the Eri silkworm in Burma, India, Ceylon, } \\
\text { Thailand and Cambodia (Weiss, E.A. 1971: pp. 8, } \\
\text { 58). }\end{array}$ \\
\hline ripened leaves & Fresh leaves & consumed as greens by Koreans (ibid.: pp. 8,58). \\
\hline large, tree-like types of castor & No preparation & $\begin{array}{l}\text { source of shade and windbreaks round the dwell- } \\
\text { ings in the Middle East (ibid.). }\end{array}$ \\
\hline castor trees & Organized in lines & $\begin{array}{l}\text { barrier and as a sand-binder on the dunes in ar- } \\
\text { eas of irrigated farming). but if it spreads quickly } \\
\text { over large areas leading to significant loss of fer- } \\
\text { tile cultivable and grazing lands (Land Protection. } \\
\text { 2001: pp. 44-45) }\end{array}$ \\
\hline castor trees & No preparation & $\begin{array}{l}\text { grown in South America as mosquito repellent } \\
\text { (http://15). }\end{array}$ \\
\hline
\end{tabular}


1- Evidence of castor plant R. communis L. is recovered from an Early Holocene site in the Central Sudan and dated to c. 7700 - 7200 bp. Those findings represent the earliest botanical evidence found -so far- from the Central Sudan. No evidence is found in the material culture remains which indicates the likelihood of its being imported.

2- Both the palaeoclimatic and palaeoecological conditions of the Central Sudan 7700 bp conformed to those required for the natural growth of castor plant. These reasons combined strongly suggest that the Early Holocene Central Sudan was part of the Eastern Tropical Africa region where castor plant is thought to have originated. 3- The earliest evidence of cultivated (and most likely domesticated) castor R. communis L. is derived from Egypt dating to $6000 \mathrm{bp}$. As Egypt is outside the natural habitat of the castor plant, the first cultivated gene pool was most likely imported from the Sudan (being the nearest and accessible natural habitat).

4- Linguistic evidence of castor plant in India dating to $4000 \mathrm{bp}$. is interpreted in favour of its being native to India. In this work, it is interpreted as being imported, most likely from Africa. However, further research is needed to verify this interpretation and that on the source of castor in Egypt (stated in point 3).

5- Different parts of castor plant and extracts removed from the plant were used for different curative and preventive medicinal applications as well as body caring, spiritual and other socio-cultural uses probably since ancient times (c. $6000 \mathrm{bp}$.) and until the present. Most of the ancient and traditional uses and applications of castor plant are strikingly similar despite their being practised in different and far apart regions in the World. Those similarities clearly indicate both continuity and spread of those uses and applica- tions over time without significant change of the original formulas or purposes of application.

6- This work clearly shows that the world-wide spread and utilization of castor plant since strongly accentuate its significant and indispensable role since ancient times. It also reflects that inedible plants, as seen in the case of castor plant, were (and still are) not less important than food plant, hence stresses the need for attending to their study in a fashion equal to that of studying food-plants.

Acknowledgement. I would like to thank Professor Isebella Caneva of Rome University, Italy, and the leader of the excavation-team of the site of Kabbashi Haitah for making it possible for me to examine a collection of potsherds excavated from the site. 


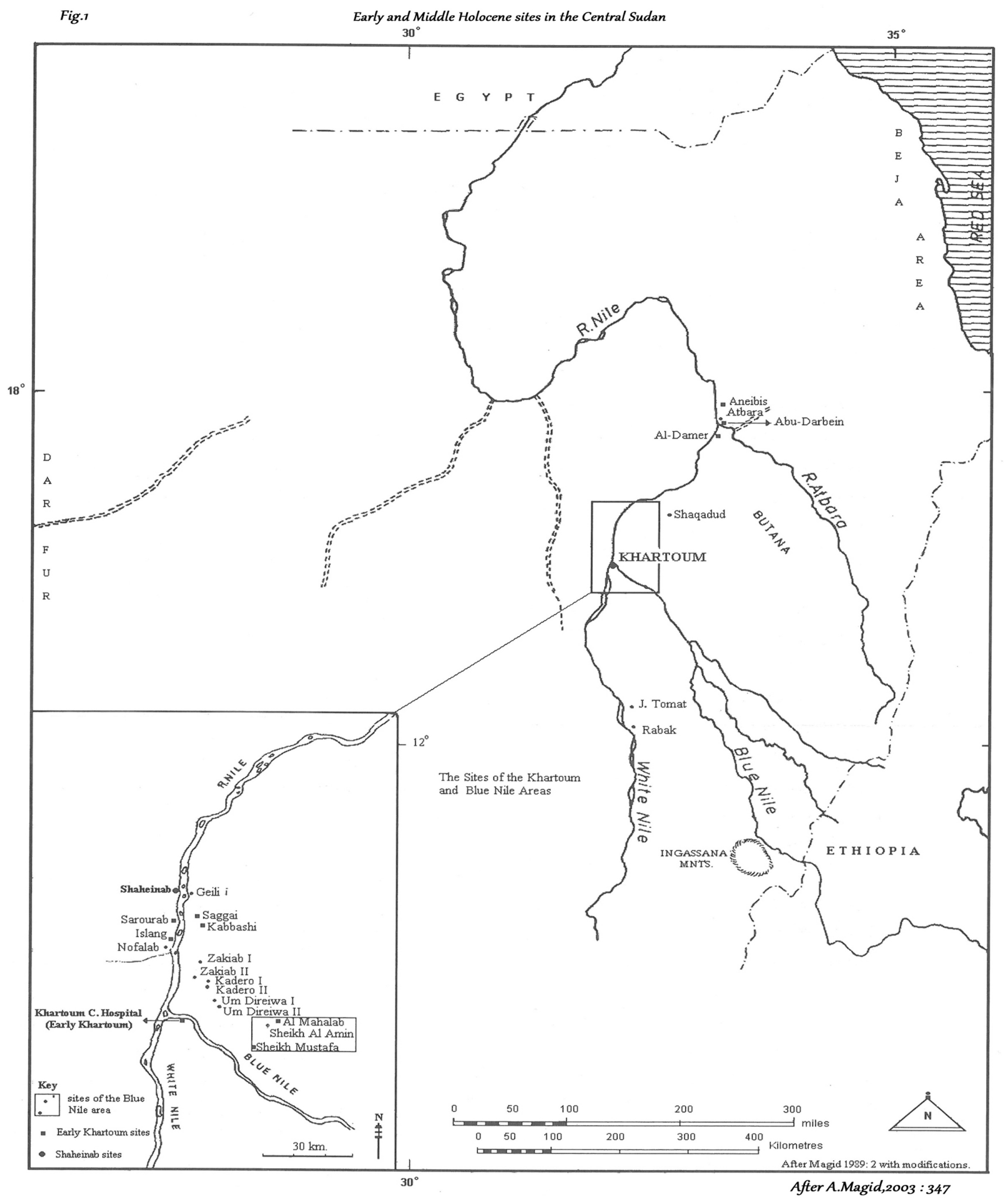




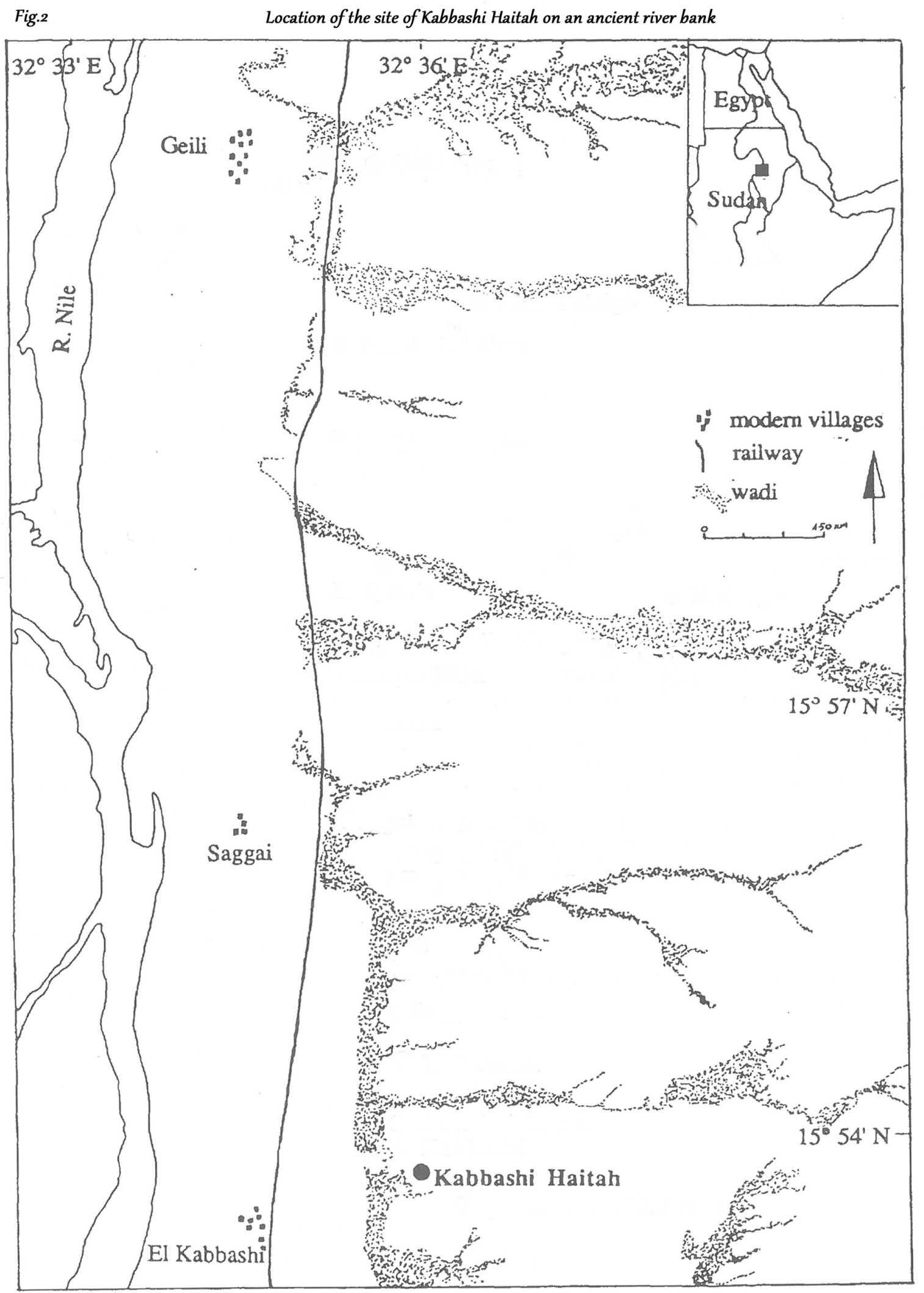

After A.Magid and 1.Caneva ,1998:8(with modifications) 


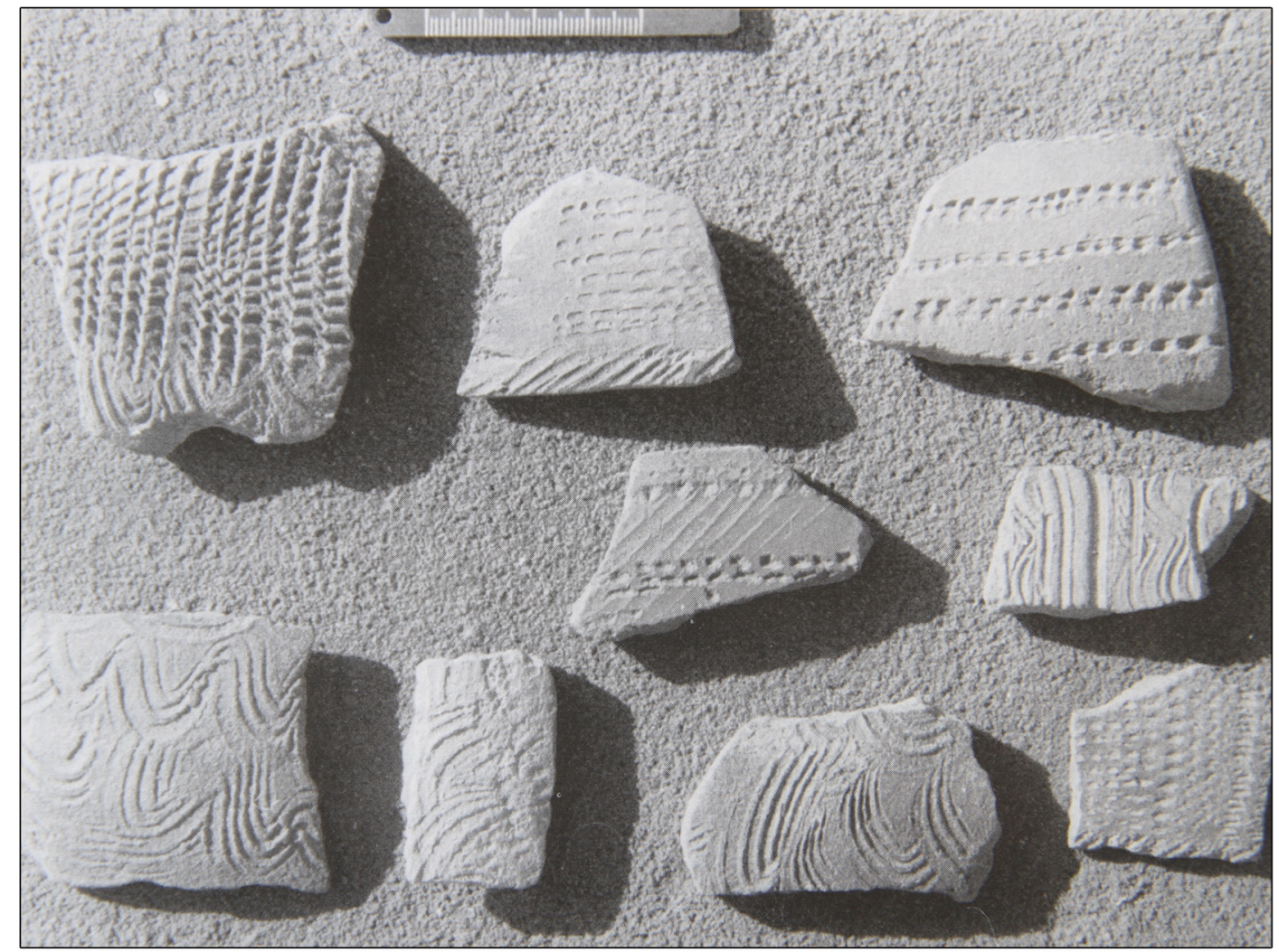

Fig 2a

Early Khartoun pottery

After Magid \& Caneva, 1998;82

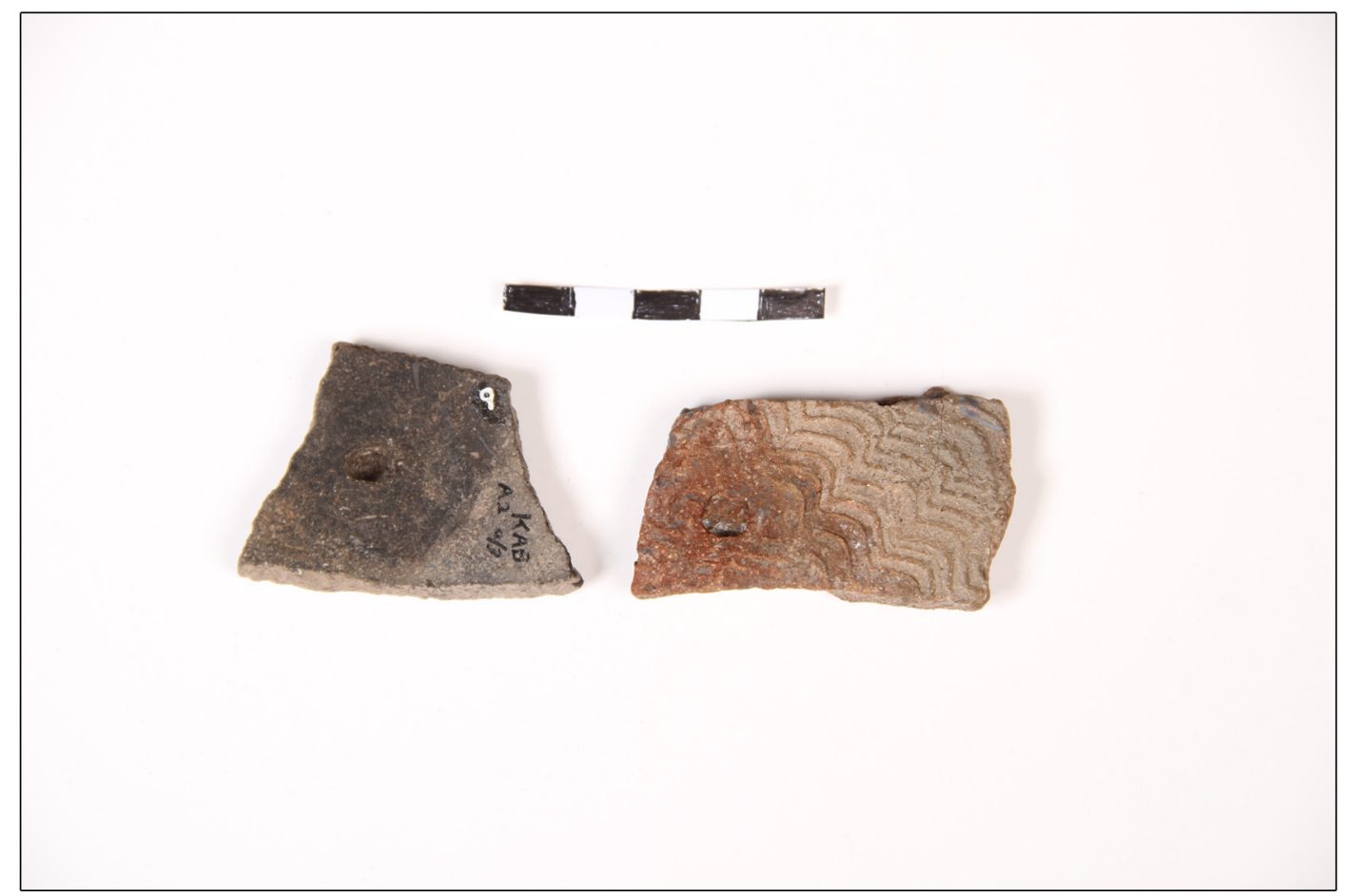

Fig $2 b$

Potsherds with impressions of castor plant -seeds 


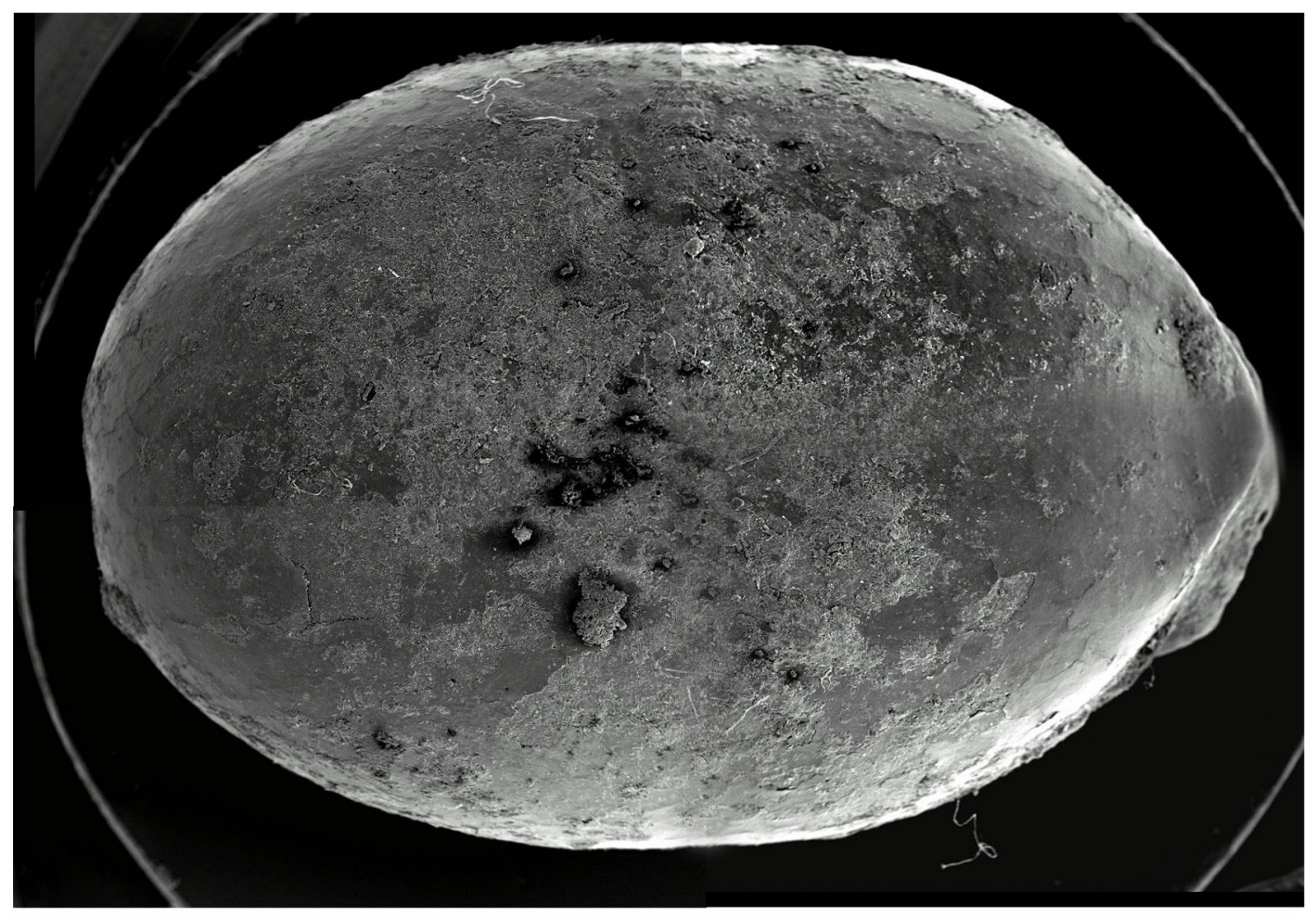

Fig 3a

Positive cast of castor plant

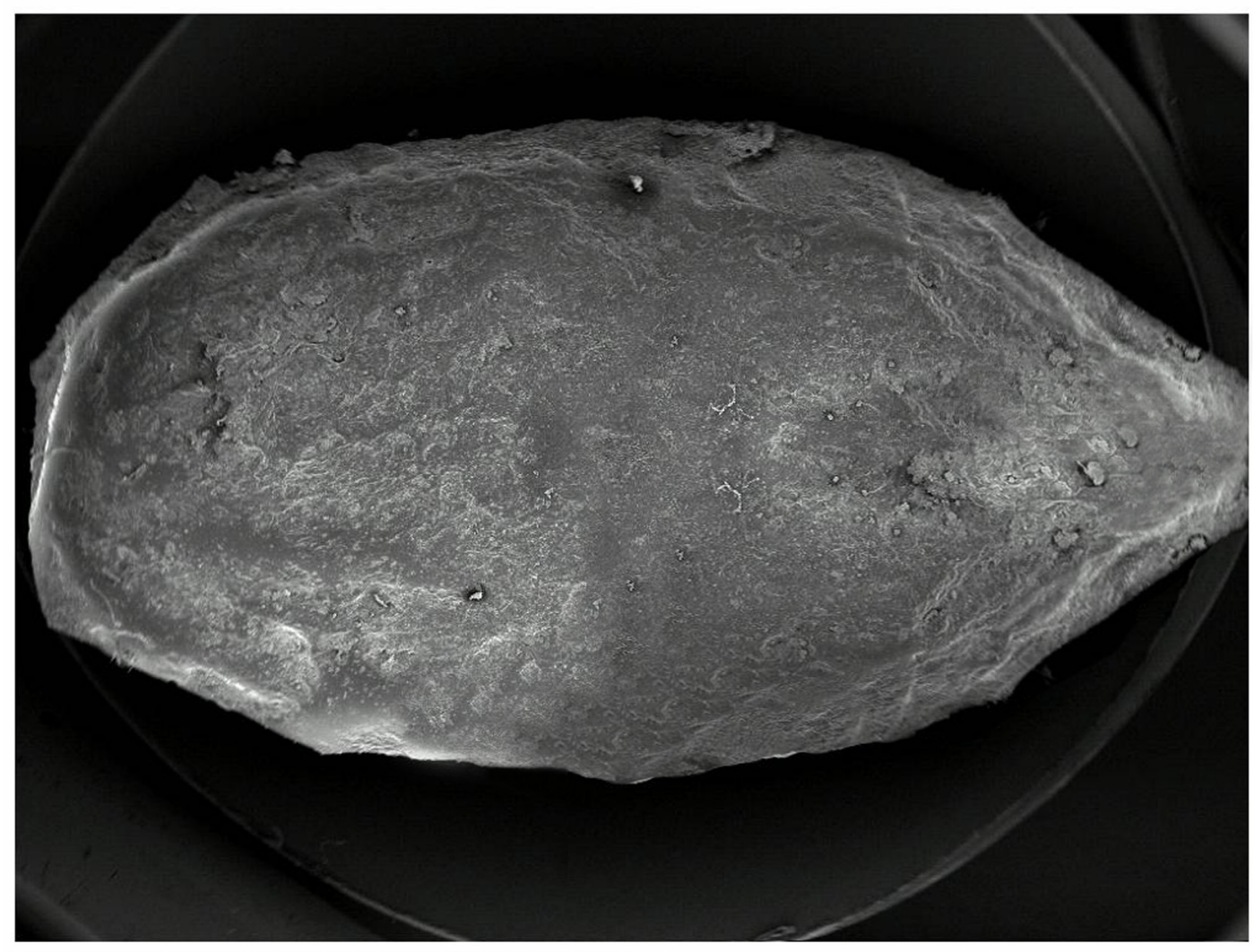

Fig 3b

Positive cast of castor plant 


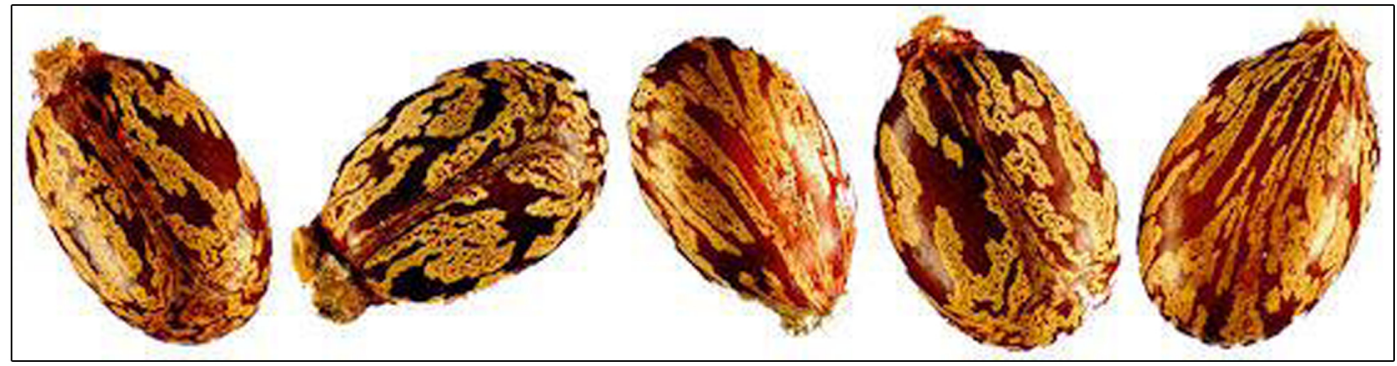

Fig 4a

Seeds of castor plant

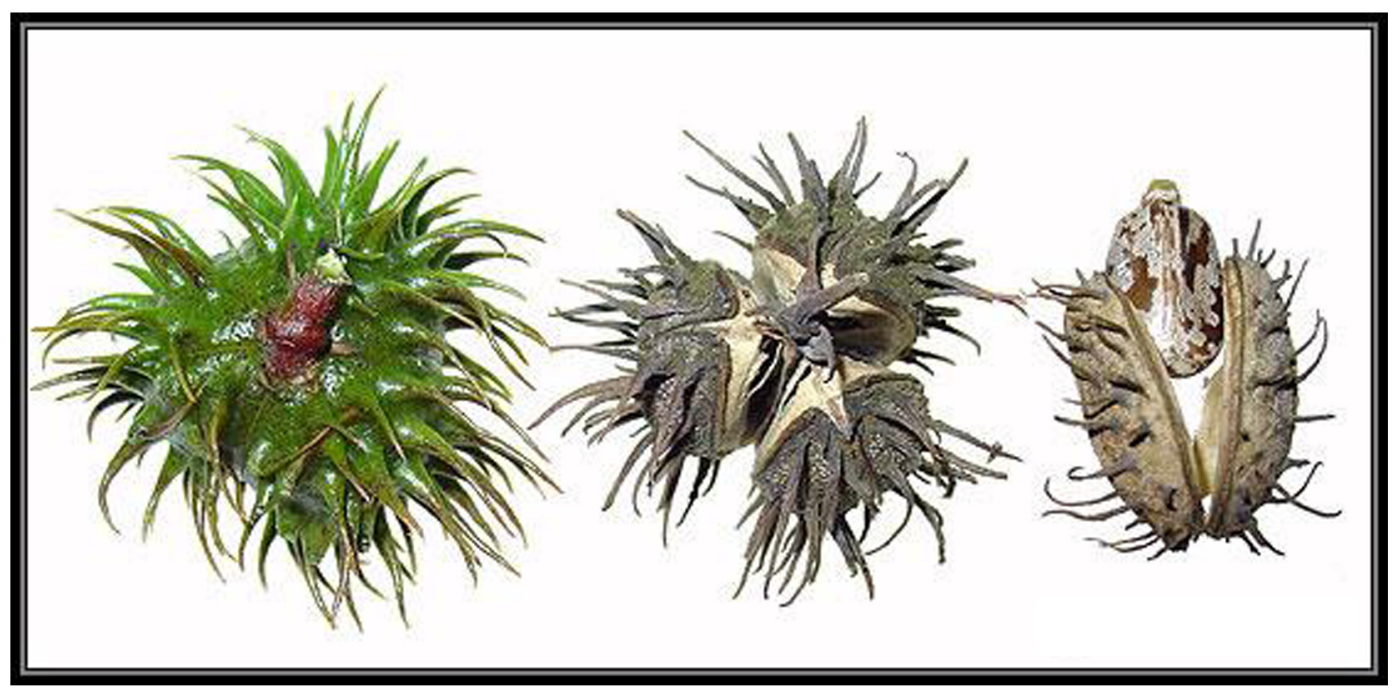

Fig $4 b$

Fruits and seeds of castor plant

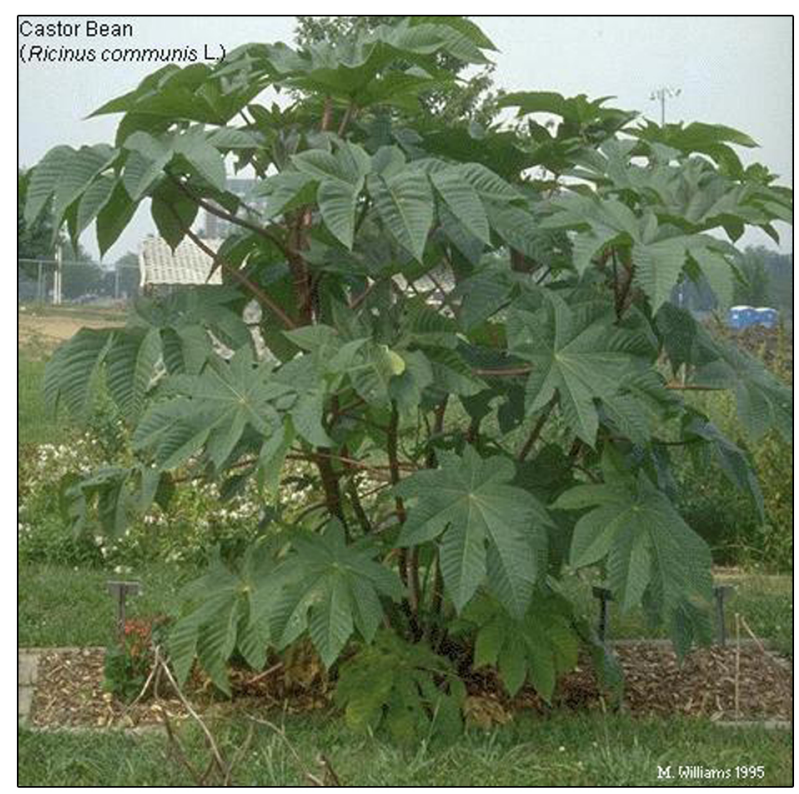

Fig 4c

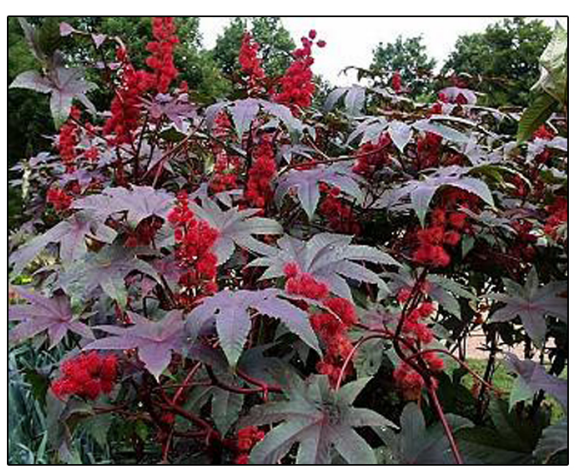

Inflorescence and coloured leaves 


\section{References :}

Al Amin, H. M, 1990, Trees and Shrubs of the Sudan. Ithaca Press Exeter.

Andrews, F.W, 1952, The Flowering Plants of the Anglo-Egyptian Sudan. Volume II.

Published by T. Bunde \& Co. Ltd. Scotland.

Arkell, A. J, 1949, Early Khartoum. Oxford University Press

Arkell, A.J, 1953, Shaheinab. Oxford University Press.

Arkell, A.J.and P.J.Ucko, 1965, Review of predynastic development in the Nile Valley. Current Anthropology 6: pp.145-156.

Brewer, J, 1992, Incremental growth Structures in the Nile Fish and Molluscs from Archaeological Sites as Indicators of Holocene Environmental Change in Egypt. The Holocene, 2: pp.30 - 36.

Balick, M.J. and P.A. Cox 1997, Plants, People and Culture. The Science of Ethnobotany.

Scientific American Library. New York.

Caneva, I.; E.A.A. Garcea; A. Gautier and W. Van Neer, 1993, Pre-Pastoral Cultures Along the Central Sudanese Nile. Quaternaria Nova, III: pp.177252.

David, N., 1976, History of Crops and Peoples in North Cameroon to A.D, 1900, In J.R. Harlan; J.M. J. De Wet (Eds.): Origins of African Plant Domestication. pp. 223-267. Mouton, Publishers, The Hague. Paris.

Dymock, W., 1893, Pharmacographia Indica. A history of the principal drugs of vegetable origin met with in British India. London: Kegan, Paul, Trench, Trubner \& Co., Ltd; Calcuta: Thacker, Spink \& Co.

El Safi, A.,n.d. Native medicine in the Sudan. Sources, Concepts and methods. Sudan Research Unit, Faculty of Arts, University of Khartoum.

Fernández, V. M., 1984, Early Meroitic in Northern Sudan: The assessment of a Nubian archaeological culture. Aula Orientalis, 2: pp. 43-84. Bar- celona, Spain.

Francaviglia, V. and A.M. Palmieri, 1983, Petrochemical Analysis of the "Early Khartoum"Pottery. In I. Caneva (Ed.): Pottery Using Gatherers and Hunters at Saggai 1 (Sudan): Preconditions for Food Production. pp. 191-203. Origini XII. Rome.

Haaland, R, 1981, Migratory Herdsmen and cultivating women. The structure of Neolithic seasonal adaotation in the Khartoum Nile Environment. University of Bergen.

Haaland, R, 1987, Socio-economic Differentiation in the Neolithic Sudan. Cambridge Monographs in African Archaeology 20. BAR International Series 350 .

Hassan, F.A, 1998, Holocene Climatic Change and Riverine Dynamics. In S. De Lernia and G. Manzi (Eds): Before Food Production in North Africa. Questions and Tools Dealing with Resource Exploitation Dynamics at $12000-7000$ bp. pp. 4351. A.B.A.C.O. Edizioní. M.A.C. sr1, Forlí.

Haynes, C. V.; .H., Elyes; L.A., Pavlish; J. C., Ritche; M., Rybak,. 1989. Holocene palaeoecology of Eastern Sahara; Salima Oasis. Quaternanry Science Review, 8 (2): pp.109- 136.

Hendrickx, S. and P. Vermeersch, 2002, Pre-History: From the Palaeolithic to the Badarian Culture. In The History of Ancient Near East.

Ibrahim, D. A, 1993, The Vegetation History of Two Mayaas (water ponds) in the Central Sudan. Unpublished M.Sc. University of Bergen, Norway. Kajale, M. D, 1991, Current Status of Indian Palaeoethnobotany: Introduced and Indigenous Food Plants with Discusssion of Historical and Evolutionary Development of Indian Agricultural Systems in General. In J. M. Refrew (Ed.): New Light in Early Farming. Recent Developments in Palaeoethnobotany. pp.155-188. Edinburgh University Press. 
Khalafalla, R.G, 2002, Vegetation History of the Southern Kordofan Savanna: A study from the Keilak and Leya Lakes (Western Sudan). Unpublished M.Sc., University of Bergen, Norway.

Klickowska, M, 1978, Preliminary Results of Palaeobotanical Studies on Plant Impressions on Potsherds from the Neolithic Settlement at Kadero. Nyame Ahuma, no. pp. 12: pp. 42-43.

Krzyzaniak, L, 1978, New Light on Early Food-Production in Central Sudan. Journal of African History, 19: pp. 159-172.

Krzyzaniak, L, 1979, Polish Excavation at Kadero. Nyame Akuma, no. 15: pp. 67-69.

Land Protection, 2001, Castor Oil Plant. Ricinus Communis. The State of Queensland Department of Natural Resources and Mines QNRM01261. pp.44-45.

Lario, J.; S. Schánchez-Moral; V.M. Fernández; A. Jimeno and M. Menéndez, 1997, Palaeoenvironmental Evolution of the Blue Nile (Central Sudan) during the Early and Middle Holocene (Mesolithic-Neolithic Transition). Quaternary Science Reviews, 16: pp. 583-588.

Loubser, J.A. 2005, Unpacking the expression "indigenous knowledge systems". Indilinga: African Journal of Indigenous Knowledge Systems, 4(6): pp. $74-88$.

Magid, A, 1982, The Khartoum Neolithic in the Light of Archaeo- ethnobotany. A case Study from the Nofalab and the Islang Sites. Unpublished M.A., University of Khartoum, Sudan.

Magid, A, 1989, Plant Domestication in the Middle Nile Basin. An Archaeoethnobotanical Case Study. Cambridge Monographs in African Archaeology 35. BAR International Series 523. Magid, A, 1995, Plant Remains and their Implications. In R. Haaland and A. Magid, (Eds.): Aqualihtic Sites along the Rivers Nile and Atbara, Sudan. 147- 177. Alma Mater, Bergen, Norway. Magid, A. 2003. Exploitation of Food-Plants in the
Early and Middle Holocene Blue Nile Area, Sudan and Neighbouring Areas. In V. M. Fernaández (Ed): Complutum. Holocene Archaeology in Ceni tral Sudan. Vol. 14: 345 - 372. University of Complutense-Madrid, Spain.

Magid, A, 2004, The study of archaeobotanical remains: Vitalising a debate on changing conceptions and possibilities. Arqueoweb, 6-1: pp. 1-15. University of Complutense Madrid publications. Magid, A, 2011, African Indigenous Knowledge Systems (AIKS): Challenges and opportunities. Africa Insight, vol 40(4) March. pp. 136-148. Africa Institute of South Africa, Pretoria, South Africa. Magid, A., and K. Krzywiniski, 1995, The Method of Positive Casts of Plant Impressions in Pottery. A Field and Laboratory Manual. Acta Palaeobotanica, 35 (1). 121 - 132.

Magid, A. and I. Caneva, 1998, Exploitation of Food Plants in the Early Holocene Central ,Sudan: A Reconsideration. In S. de Lernia and G. Manzi, (Eds.):

Before food production in North Africa. Questions and tools dealing with resource exploitation dynamics at $12000-7000$ bp. A.B.A.C.O. Edizioní. M.A.C. sr1, Forlí: 79-89.

Mazonde, I.N, 2010, Protecting, preserving and managing African Indigenous Knowledge

Systems. Unpublished paper presented in a Summit on Indigenous Knowledge Systems, held in Gaborone, Botswana, 10 -11/March..

Midant-Reynes, B, 1992, The Prehistory of Egypt. From the first Egyptian to the first Pharaohs. Ian Shaw (Trans.) 2000, First edition of English translation by Blackwell Publishing.

Moerman, D. E, 1986, Medicinal Plants of Native America, Volume One. University of Michigan, Museum of Anthropology. Ann Arbor. U.S.A. Mohammed-Ali, A.S, 1982, The Neolithic period in the Sudan c. $6000-2500$ B.C. Cambridge monographs in Archaeology 6, BAR international 
series139.

Moldenke, H.N., and A.L. Moldenke, 1952, Plants of the Bible. Published by Chronica Botanica Company. U.S.A.

Murty, S., and N.S. Subrahmanyam. 1989. A Textbook of Economic Botany. Wiley Eastern Limited. New Delhi, Bombay, Calcuta, Madras.

Muschler, R, 1912, A Manual Flora of Egypt, Vol. 1. Berlin, R. Friedlaender \& Sohn, Karlstrasse II. Purseglove, J.W, 1976, The Origins and Migrations of Crops in Tropical Africa. In J.R. Harlan; J.M. J. De Wet (Eds.): Origins of African Plant Domestication. 291-309. Mouton, Publishers, The Hague. Paris.

Quer, P.F, 1985, Plantas Medicinales. El Dioscórides Renovado. Editorial Labor, S.A.

Shaw; T, 1976, Early Crops in Africa: A Review of Evidence. In J.R. Harlan; J.M. J. De Wet (Eds.): Origins of African Plant Domestication. pp. 107-153. Mouton, Publishers, The Hague. Paris.

Telesko, W, 2001, The wisdom of nature. The healing powers and symbolism of plants and animals in the Middle Ages. Prestel verlag. Munich. London. New York.

Sir Hort, A, 1948, Theophrastus. Enquiry into plants and minor- works on weather signs, Vol. 1. University of Harvard Press. London, Cambridge, Massachusetts

Simpson, B. B., and M. Conner-Ogorzaly, 2000, Economic botany: plants in our world. McGrawHill Higher Education.

Webster Dictionary, 1913, Webster's 1913 Dictionary.

Weiss, E.A, 1971, Castor, sesame and safflower. Leonard Hill, London.

Williams, M.A.J. ; D.A. Adamson (Eds),1982, A land between Two Niles. Quaternary Geology and Biology of the Central Sudan. Balkema, Rotterdam.

Zohary, M, 1982, Plants of the Bible. Cambridge
University Press. Cambridge. London, New York, Sydney.

Internet Sites.

http://1. Ricinus communis, L. Castorbean. http:// www.plantdatabase.com/go/70/(accessed. 15.07.2012).

Grieve, M., Grieve, M. http://2. A Modern Herbal|Castor Oil Plant http://www.botanical. com/botanical/ mgmh/c/casoil32.html (accessed 15. 07.2012).

http://3. Castor Bean Plant.http://www.waynesword.palomar.edu/plmar99.htm (accessed 10. 07.2012).

http://4. Castorbean. http://www.ansci.cornell. edu/plants/castorbean.htm\# description (accessed 15. 07.2012).

http://5. Castor oil. http://www.wikipedia.org/ wiki/castor_oil (visited10.07.2012.).

http://6. Ricin. http://www.chiron.valdosta.edu/ rgoddard/biol4900/corbett/corbett2.htm (accessed 11. 07.2012).

http://7. Ricinus communis seeds. http:// www.comp.leeds.ac.uk/cgibin/pfaf/arr_html? Ricinus+communis (accessed 08. 07.2012).

http://8. Ricinus communis seeds. http:// www.inchem.org/documents/pims/plant/ ricinus. htm\#PartTitle:1.\%20NAME (accessed 05.07.2012.).

http://9. Castor oil: Uses. http://www.annieappleseedproject.org/castoroiluses.htm (accessed 10. 07.2012).

http://10. Medication in Ancient Egypt. http:// www.cartage.org.Ib/en/themes/GeogHist /histories/Oldcivilization/Egyptology/Medication/Medica (accessed 15. 07.2012).

http://11. Castor Oil. http://www.hashmi.com/ castor.html (accessed 11. 07.2012).

http://12. How Deadly Is Ricin?. http://www.museum.gov.ns.ca/poison/castor.htm (accessed 12. 
07.2012).

$\mathrm{http}: / / 13$. Ricinus communis http://www.floridata.com/ref/r/rici_com.cfm (accessed 06. 07.2012).

http://14.Jamaican Maroons. http://en.wikipedia. org/wiki/Jamaica_Maroons(accessed 30.07.2012)

http://15. Castor Bean Seed- Medicine Herb Online. http://www.egregore.com/ herbs/ Castorbean.htm\#Name (accessed 11. 07.2012). 